\title{
Relative contribution of contact and complement activation to inflammatory reactions in arthritic joints
}

\author{
J J Abbink, A M Kamp, J H Nuijens, A J M Eerenberg, A J G Swaak, C E Hack
}

\begin{abstract}
Although both the complement and contact system are thought to contribute to the inflammatory reaction in arthritic joints, only activation of complement has so far been well established, whereas contact activation and its contribution to arthritis has not been systematically explored. Complement and contact activation were assessed in 71 patients with inflammatory arthropathies and 11 with osteoarthritis using sensitive assays for $\mathrm{C} 3 \mathrm{a}$, and C1-inhibitor (C1INH)-kallikrein and CIINH-factor XIIa complexes respectively.

Increased plasma concentrations of kallikrein- and factor XIIa-CIINH complexes were found in two and seven of the 71 patients with inflammatory arthropathies, respectively, and in none of the patients with osteoarthritis. Increased synovial fluid concentrations of kallikrein and factor XIIa complexes occurred in 13 and 15 patients with inflammatory joint diseases respectively, and in two patients with osteoarthritis. Contact system parameters did not correlate with clinical symptoms, local activity, or neutrophil activation.
\end{abstract}

In contrast, synovial fluid concentrations of $\mathrm{C} 3 \mathrm{a}$ and $\mathrm{C1INH}-\mathrm{Cl}$ complexes were increased in all patients and in $\mathbf{2 0}$ patients with inflammatory arthropathies respectively, and were higher in patients with a higher local activity score. Synovial fluid C3a correlated with parameters of neutrophil activation such as lactoferrin. Increased plasma concentrations of $\mathrm{C} 3 \mathrm{a}$ and $\mathrm{C} 1 \mathrm{INH}-\mathrm{Cl}$ complexes occurred in 13 and 11 patients with inflammatory joint diseases, and in one and two patients with osteoarthritis respectively. Plasma concentrations of $\mathrm{C} 3 \mathrm{a}$ correlated with the number of painful joints.

Thus contact activation occurs only sporadically in patients with arthritis and contributes little if anything to the local inflammatory reaction and neutrophil activation. These latter events are significantly related to the extent of complement activation.

(Ann Rheum Dis 1992; 51: 1123-1128)

Neutrophils are the predominant cells present in the synovial cavity of patients with rheumatoid arthritis (RA) and gout. ${ }^{12}$ The presence of increased concentrations of elastase, lactoferrin, and other neutrophil granule constituents in arthritic joints suggests that these cells are activated. ${ }^{34}$ Activation of the complement and the contact system results in the production of factors that are chemotactic or agonistic, or both, for neutrophils in vitro (for review, see Vogt $^{5}$ and Kaplan 6 ).

Evidence for complement activation in arthritic joints is abundant. For example, increased concentrations of split products of the third component of the complement system, C3, in joints of patients with RA and gout have often been reported. ${ }^{71}$ Intra-articular complement activation has also been shown to correlate with leucocyte levels. ${ }^{11-13}$

The contact system of coagulation is also thought to contribute to the inflammatory response observed in arthritis (for reviews, see Kaplan $^{6}$ and Cochrane and Griffin ${ }^{14}$ ). Activation of this pathway generates active factor XII (factor XIIa) and kallikrein. ${ }^{6} 14$ Kallikrein cleaves bradykinin, a potent vasodilator, from its precursor high molecular weight kininogen. Kallikrein and factor XIIa can aggregate neutrophils and cause elastase secretion. ${ }^{15-17}$ The presence of kinins in arthritic joints has long been recognised. ${ }^{18}{ }^{19}$ The role of contact activation in the generation of these, however, and the contribution of this system to the arthritic reaction in relation to complement activation has not yet been explored.

Factor XIIa and kallikrein are inhibited by the serine proteinase inhibitor, $\mathrm{CIINH},{ }^{20} 21$ which is also the only known inhibitor of activated $\mathrm{Cls}$ and $\mathrm{Clr}$ from the classical pathway of complement. ${ }^{22}$ As factor XIIa and kallikrein readily form complexes with $\mathrm{CIINH}$, complexes between $\mathrm{C} 1 \mathrm{INH}$ and kallikrein and factor XIIa are currently measured to assess contact activation in biological states. ${ }^{23}$

We have developed highly sensitive assays for $\mathrm{C}^{2} \mathrm{a}^{24}$ and $\mathrm{ClINH}$-kallikrein and C1INH-factor XIIa complexes. ${ }^{23}$ In the work reported here we used these assays to study the occurrence of contact activation in 71 patients with inflammatory arthropathies and 11 patients with osteoarthritis. We also assessed the relative contribution of complement and contact activation to clinical symptoms in these patients.

Patients and methods

PATIENTS AND SAMPLES

The study was approved by the medical ethical committee of the Daniel Den Hoed Clinic. Eighty two patients ( 37 women, 45 men) who visited the outpatient clinic of the hospital were studied. Their median age was 49 years (range 16-94). Fifty two patients had RA, seven gout, 12 seronegative spondyloarthropathies, and 11 osteoarthritis. Patients with RA fulfilled the respective American Rheumatism Association criteria. ${ }^{25}$ Gout was diagnosed based on the 
presence of at least five of the criteria described by Wallace et al. ${ }^{26}$ All seven patients who fulfilled these criteria had chronic gout. Patients with seronegative spondyloarthropathies included two with ankylosing spondylarthritis defined according to the New York criteria, ${ }^{27}$ four with psoriatic arthritis as diagnosed by the presence of characteristic skin lesions or nail pits, one with Reiter's syndrome (seronegative peripheral arthritis with a non-specific conjunctivitis), and five patients had 'unclassifiable' seronegative peripheral arthritis as described by Prakash et al. ${ }^{28}$ Patients with osteoarthritis had knee radiographs showing loss of cartilage, subchondral sclerosis or osteophytes, or both. The activity of the disease was estimated in 49 patients ( 38 patients with RA, three with gout, and eight with seronegative spondylarthritis) by assessing the Ritchie index. In 48 patients the aspirated joint was examined and assessed for parameters of inflammation: increased warmth ( $0-2$ points), effusion ( $0-2$ points), tenderness (0-2 points), and swelling (0-2 points). From these parameters the local activity was calculated ( $0-8$ points).

Synovial fluid was aspirated from the joint (from the knee in 79 patients and from the shoulder in three) when therapeutically indicated (clinically inflamed or an effusion persistent for at least three months) with a plastic syringe and placed immediately in a siliconised vacuum tube that contained $10 \mathrm{mM}$ EDTA and $0.05 \%(w / v)$ Polybrene (hexadimethrine bromide from Janssen (Beersse, Belgium)) to prevent in vitro activation of the complement and contact systems. ${ }^{23}$ Blood from patients was collected at the time of arthrocentesis in similar tubes to those used for synovial fluid. Cells were removed by centrifugation and synovial fluid and plasma samples were stored in aliquots at $-70^{\circ} \mathrm{C}$ until tested Plasma samples from 28 healthy volunteers were collected in a similar manner as from the patients and stored at $-70^{\circ} \mathrm{C}$ in individual aliquots and in a pool prepared by mixing equal volumes of plasma from each subject (pooled normal plasma).

\section{METHODS}

Complexes between CIINH and factor XIIa, kallikrein, or activated $\mathrm{Cl}$ were measured as described previously. ${ }^{23}$ (In this paper, CIINH$\mathrm{Cl}$ complexes designate the complex that consists of activated $\mathrm{Cls}$, activated $\mathrm{Clr}$, and C1INH, in a molar ratio of $1: 1: 2$.) In brief, a monoclonal antibody which specifically reacts with complexed $\mathrm{C} 1 \mathrm{INH},{ }^{23} \mathrm{mcAb}-\mathrm{KOK} 12$, was coupled to Sepharose (cyanogen bromide activated Sepharose 4B from Pharmacia Fine Chemicals (Uppsala, Sweden)), and incubated with samples. Bound ClINH-factor XIIa, ClINH-kallikrein, and C1INH-Cl complexes were subsequently detected by incubation with purified ${ }^{125} \mathrm{I}$-labelled polyclonal antibodies to factor XIIa, kallikrein, and $\mathrm{Cls}$ respectively. Concentrations of complexes were expressed in nmol/l by reference to dextran sulphate activated plasma $^{23}$ (containing $375 \mathrm{nM}$ C1INH-factor XIIa and 341 nM CIINH-kallikrein complexes) or to serum to which aggregated IgG was added $^{29}$ (containing $360 \mathrm{nM}$ ClINH-Cl complexes). Plasma and synovial fluid concentrations of complexes in patients were considered to be increased when they exceeded the mean $+2 \mathrm{SD}$ of the plasma concentrations in 28 healthy volunteers, i.e. $>0 \cdot 19 \mathrm{nM}$ for $\mathrm{C} 1 \mathrm{INH}$ factor XIIa, $>0.85 \mathrm{nM}$ of ClINH-kallikrein, and $>18 \mathrm{nM}$ for $\mathrm{ClINH}-\mathrm{Cl}$ complexes.

Concentrations of $\mathrm{C} 3 \mathrm{a}$, prekallikrein, factor XII, functional CIINH, and total CIINH in plasma and synovial fluid were determined by radioimmunoassay as described previously. ${ }^{23} 24$ (In plasma, and presumably also in synovial fluid, C3a is rapidly converted to $\mathrm{C} 3 \mathrm{a}_{\text {desarg. In }}$ this paper we use $\mathrm{C} 3 \mathrm{a}$ to designate both $\mathrm{C} 3 \mathrm{a}$ and $\mathrm{C} 3 \mathrm{a}_{\text {desarg. }}$.) C5a concentrations were determined with a commercially available kit obtained from Behringwerke (Marburg, Germany).

Concentrations of inactivated cleaved ClINH, i.e. C1INH cleaved at or near its reactive site, were measured as described previously with a monoclonal antibody that specifically reacts with this form of CIINH. ${ }^{30}$

\section{STATISTICAL ANALYSIS}

Data were analysed with a standard statistical computer program (SPSS-PC). The normal distribution of the data was checked at a $0.05 \%$ level of significance by the KolmogorovSmirnov test.

Differences in plasma and synovial fluid concentrations of various parameters between patient groups were evaluated with Student's $t$ test when parameters were distributed normally and with the Wilcoxon-MannWhitney test otherwise. A p value of less than 0.05 was considered to indicate statistical significance.

The relation between parameters was studied with linear regression (Pearson product moment correlation when parameters were distributed normally, and Spearman rank correlation otherwise). To correct for multiple correlations, only a $p$ value less than 0.005 was considered to indicate a significant correlation.

\section{Results}

CONTACT ACTIVATION IN SYNOVIAL FLUID

Concentrations of C1INH-kallikrein and CIINH-factor XIIa complexes in synovial fluid from 71 patients with inflammatory arthropathies and 11 patients with osteoarthritis are shown in fig 1. Concentrations of the two complexes were comparable in all patient groups. Increased concentrations of $\mathrm{ClINH}$ kallikrein complexes were found in seven of 52 patients with RA, four of seven patients with gout, three of 12 patients with seronegative spondyloarthropathies, and two of 11 patients with osteoarthritis. Increased concentrations of CIINH-factor XIIa complexes were found in 10 patients with RA, two with gout, three with seronegative spondyloarthropathies, and two with osteoarthritis. CIINH-kallikrein and CIINH-factor XIIa complexes correlated strongly with each other $\left(\mathrm{r}=0.78 ; \mathrm{p}<10^{-9}\right)$. Total synovial fluid concentrations of factor XII 

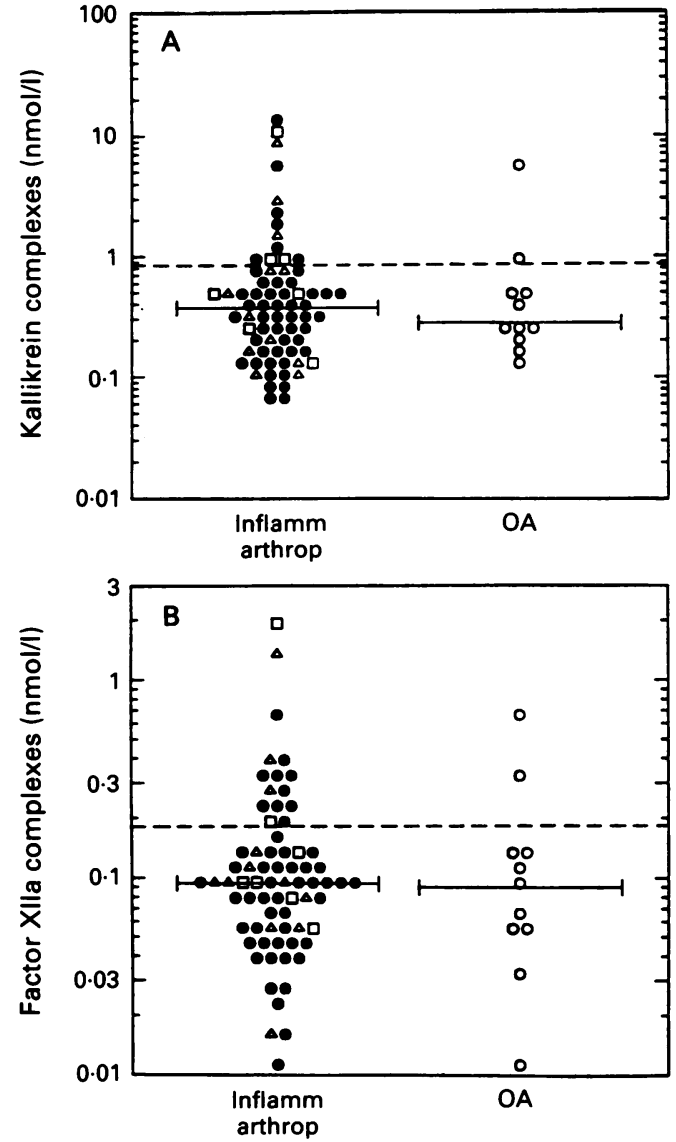

Figure 1 Synovial fluid concentrations of CIINH complexes in patients with inflammatory arthropathies. The concentrations of CIINH-kallikrein complexes $(A)$ and CIINH-factor XII a complexes $(B)$ in synovial fluid from 52 patients with rheumatoid arthritis $(\mathbf{O})$, seven patients with gout $(\square), 12$ patients with seronegative spondyloarthropathies $(\triangle)$, and 11 with osteoarthritis $(O)$ are shown. The broken lines indicate the highest level of CIINH-kallikrein $(A)$ and $C I I N H$-factor XII a complexes $(B)$ respectively, detected in plasma from 28 healthy volunteers; the solid lines indicate the median of the patient group presented.

did not differ between patient groups, whereas total concentrations of prekallikrein were higher in synovial fluid from patients with inflammatory joint diseases compared with osteoarthritis $(\mathrm{p}<0.05$, table 1$)$. The percentage of complexed kallikrein and factor XII, i.e. the concentration of complexes compared with the total concentration of prekallikrein/kallikrein and factor XII respectively, was 0.08 and $0.04 \%$ in plasma, and 0.21 and $0.09 \%$ in synovial fluid, and was significantly higher in synovial fluid than in plasma $(p<0.00001$ for C1INHkallikrein and C1INH-factor XIIa complexes). Synovial fluid concentrations of total and inactivated CIINH were higher in patients with inflammatory joint diseases compared with osteoarthritis $(p<0.001$ for both, table 2$)$. When the amount of inactivated CIINH was expressed as a fraction of total $\mathrm{CIINH}$, however, no significant difference was found between these patient groups $(p=0 \cdot 370)$. Also the functional index of $\mathrm{ClINH}$, i.e. the ratio of functional/antigenic CIINH, did not differ significantly between patient groups. None of the contact system parameters correlated with local activity of the joints.

CONTACT ACTIVATION IN PLASMA

In plasma from 71 patients with arthritis, we occasionally found increased concentrations of CIINH complexes (table 2). Six patients (five with RA and one with gout) had increased ClINH-factor XIIa complexes (i.e. $>0 \cdot 19 \mathrm{nM}$ ) and three patients (all with RA) had increased C1INH-kallikrein complexes (i.e. $>0.85 \mathrm{nM}$ ). In two of 28 volunteers we also found increased concentrations of $\mathrm{ClINH}$-kallikrein and CIINH-factor XIIa complexes. Concentrations of total, functional, and inactivated $\mathrm{ClINH}$ in plasma from patients with inflammatory joint diseases were significantly higher than in plasma from patients with osteoarthritis and healthy volunteers. The fraction of inactivated CIINH

Table 1 Contact system parameters in various arthropathies. Results are mean $(S D)$

\begin{tabular}{|c|c|c|c|}
\hline & $\begin{array}{l}\text { Inflammatory } \\
\text { arthropathies } \\
(n=7 I)\end{array}$ & $\begin{array}{l}\text { Osteoarthritis } \\
(n=I I)\end{array}$ & $\begin{array}{l}\text { Healthy } \\
\text { volunteers } \\
(n=28)\end{array}$ \\
\hline $\begin{array}{l}\text { Prekallikrein (\% normal) } \\
\text { Plasma* } \\
\text { Synovial fluid } \dagger\end{array}$ & $\begin{array}{l}90(21) \\
46(16)\end{array}$ & $\begin{array}{r}111(31) \\
35(11)\end{array}$ & $100(22)$ \\
\hline $\begin{array}{l}\text { Factor XII (\% normal) } \\
\text { Plasma } \\
\text { Synovial fluid }\end{array}$ & $\begin{array}{l}97(36) \\
56(25)\end{array}$ & $\begin{array}{r}108(44) \\
47(16)\end{array}$ & $\begin{array}{l}95(29) \\
-\end{array}$ \\
\hline
\end{tabular}

Table 2 CIINH species in patients with various arthropathies. Results are mean (SD) except for CIINH which is median (range)

\begin{tabular}{|c|c|c|c|c|c|c|c|c|}
\hline & \multicolumn{2}{|c|}{$\begin{array}{l}\text { Total CIINH } \\
(\mu M)\end{array}$} & \multicolumn{2}{|c|}{$\begin{array}{l}\text { Functional CIINH } \\
(\mu M)\end{array}$} & \multicolumn{2}{|c|}{$\begin{array}{l}\text { Functional index } \\
\text { (functional/antigenic) }\end{array}$} & \multicolumn{2}{|c|}{$\begin{array}{l}\text { Inactivated CIINH } \\
(n M)\end{array}$} \\
\hline & Plasma* & $\begin{array}{l}\text { Synovial } \\
\text { fluidf }\end{array}$ & Plasmaf & $\begin{array}{l}\text { Synovial } \\
\text { fluidt }\end{array}$ & Plasma & $\begin{array}{l}\text { Synovial } \\
\text { fluid }\end{array}$ & Plasmat & $\begin{array}{l}\text { Synovial } \\
\text { fluid! }\end{array}$ \\
\hline Inflammatory arthrop & $3 \cdot 7(0 \cdot 8)$ & $1 \cdot 7(0 \cdot 8)$ & $3 \cdot 8(1 \cdot 1)$ & $1.5(0.5)$ & $1 \cdot 03(0 \cdot 19)$ & $0.94(0 \cdot 18)$ & $103(53-262)$ & $68(17-172)$ \\
\hline $\begin{array}{l}(\mathbf{n}=52) \\
\text { Gout }(\mathbf{n}=7) \\
\text { Seronegative }\end{array}$ & $\begin{array}{l}3.6(0.8) \\
4 \cdot 2(0.5)\end{array}$ & $\begin{array}{l}1.8(0.7) \\
1.8(0.6)\end{array}$ & $\begin{array}{l}3.9(1.1) \\
3.9(0.5)\end{array}$ & $\begin{array}{l}1.5(0.5) \\
1.8(0.3)\end{array}$ & $\begin{array}{l}1.07(0.19) \\
0.94(0.12)\end{array}$ & $\begin{array}{l}0.92(0.18) \\
1.05(0.28)\end{array}$ & $\begin{array}{r}105(63-262) \\
91(71-152)\end{array}$ & $\begin{array}{l}75(20-172) \\
62(34-126)\end{array}$ \\
\hline $\begin{array}{l}\text { spondyloarthropathies } \\
(\mathrm{n}=12)\end{array}$ & $3.6(0.9)$ & $1.5(0.5)$ & $3.5(0.6)$ & $1.4(0.5)$ & $0.98(0.14)$ & $0.96(0.09)$ & $102(53-187)$ & $60(17-107)$ \\
\hline Osteoarthritis $(n=11)$ & $3.0(0.7)$ & $1 \cdot 0(0 \cdot 4)$ & $3 \cdot 1(0 \cdot 6)$ & $0.9(0.3)$ & $1.04(0.08)$ & $0.94(0.25)$ & $92(68-136)$ & $31(18-63)$ \\
\hline Healthy volunteers $(n=28)$ & $2.9(0.7)$ & & $2.9(0.6)$ & & $0.99(0.09)$ & & $73(34-138)$ & \\
\hline
\end{tabular}

${ }^{*}$ The inflammatory group was different from both the group with osteoarthritis $(p=0.017)$ and from healthy volunteers $(p<0 \cdot 0001)$. $\dagger$ The inflammatory group was different from the group with osteoarthritis $(p<0.02)$

†The inflammatory group was different from the healthy volunteers $(p<0 \cdot 0001)$.

¿The inflammatory group was different from the group with osteoarthritis $(p<0 \cdot 0001)$. 
(inactivated $\mathrm{ClINH}$ /antigenic $\mathrm{ClINH}$ ) was higher in patients with gout compared with healthy volunteers $(p=0.038)$, patients with $R A$ $(p=0.023)$, and patients with osteoarthritis $(\mathrm{p}=0.03)$.

Plasma concentrations of prekallikrein were lower in patients with inflammatory joint diseases compared with healthy volunteers $(p=0.045)$ and patients with osteoarthritis $(p=0.008)$ (table 1$)$. In the group of patients with inflammatory arthropathies, patients with RA had lower plasma concentrations of prekallikrein compared with patients with gout $(p=0.009)$. Plasma concentrations of factor XII did not differ significantly between patient groups nor between patient groups and healthy volunteers. No correlation between contact activation parameters in plasma and clinical symptoms was found.

\section{COMPLEMENT ACTIVATION IN SYNOVIAL FLUID}

In synovial fluid from patients with inflammatory joint diseases concentrations of $\mathrm{C} 3 \mathrm{a}$ and CIINH-Cl complexes were higher than in patients with osteoarthritis $(p=0.006$ and $\mathrm{p}<0.0001$ respectively, table 3 ). The highest concentration of $\mathrm{C} 3 \mathrm{a}$ found in patients with osteoarthritis was $81 \mathrm{nM}$, whereas 42 of the 71 patients with inflammatory arthropathies had C3a concentrations greater than $80 \mathrm{nM}$.

In 42 patients we also measured $\mathrm{C} 5 \mathrm{a}$ concentrations. In 25 patients with RA mean (SD) plasma concentrations were $5 \cdot 1(3.4) \mathrm{ng} / \mathrm{ml}$ whereas synovial fluid concentrations were 14 $(11.4) \mathrm{ng} / \mathrm{ml}$. In three patients with gout these concentrations were $4.3(3.2)$ and $4.3(1.5)$, in nine patients with seronegative spondyloarthropathies $5.9(2.4)$ and $6.6(4.5)$, and in five patients with osteoarthritis $3.9(2 \cdot 1)$ and 4.3 $(3 \cdot 2)$ respectively. $\mathrm{C} 3 \mathrm{a}$ and $\mathrm{C} 5 \mathrm{a}$ concentrations correlated with each other $\left(r=0.74 ; p<10^{-7}\right)$, with $\mathrm{ClINH}-\mathrm{Cl}$ complexes $(\mathrm{r}=0.78$ and $\mathrm{r}=0.71$ with $\mathrm{p}<10^{-6}$ for both), and with levels of inactivated C1INH $(r=0.67$ and $r=0.62$ with $\mathrm{p}<10^{-4}$ for both). C3a and C5a concentrations also correlated with parameters of neutrophil activation such as lactoferrin $(\mathrm{r}=0.58$ and $r=0.67$ with $p<10^{-8}$ for both) (table 4). In 48 patients (37 with RA, three with gout, and eight with seronegative spondylarthritis) the local activity of the aspirated joint was clinically assessed. When patients were divided into two

Table 3 Concentrations of C3a and CIINH-CI complexes in various arthropathies. Results given as median (range)

\begin{tabular}{|c|c|c|c|c|}
\hline & \multicolumn{2}{|l|}{$C 3 a$} & \multicolumn{2}{|c|}{ CIINH-CI complexes } \\
\hline & Plasma* & Synovial fluidt & Plasma* & Synovial fluid \\
\hline \multirow[t]{2}{*}{$\begin{array}{l}\text { Inflammatory arthropathies } \\
\text { Rheumatoid arthritis }(\mathrm{n}=52) \\
\text { Gout }(\mathrm{n}=7) \\
\text { Seronegative spondyloarthro- } \\
\text { pathies }(\mathrm{n}=12)\end{array}$} & 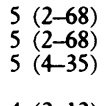 & $\begin{array}{c}93(10-1098) \\
106(16-1098) \\
72(20-365)\end{array}$ & $\begin{array}{l}12(1-35) \\
13(4-29) \\
8(5-20)\end{array}$ & $\begin{array}{l}10(1-67) \\
16(1-67) \\
9(2-14)\end{array}$ \\
\hline & $4(2-12)$ & $33(10-132)$ & $10(1-35)$ & $5(1-14)$ \\
\hline Osteoarthritis $(n=11)$ & $4(2-9)$ & $24(12-81)$ & $11(4-24)$ & $6(1-12)$ \\
\hline Healthy volunteers $(n=28)$ & $3(2-22)$ & & $8(4-18)$ & \\
\hline
\end{tabular}

The inflammatory group was different from the healthy volunteers $(p=0.006$ for $\mathrm{C} 3 \mathrm{a}$, and $\mathrm{p}<0.0001$ for CiIN $\mathrm{H}-\mathrm{Cl}$ ).

The inflammatory group was different from the group with osteoarthritis $(p=0.001$ for $\mathrm{C} 3 \mathrm{a}$ and $p=0.007$ for CIINH-Cl). The group with rheumatoid arthritis was different from the group with osteoarthritis $(p=0.0002$ for $\mathrm{C} 3 \mathrm{a}$ and $\mathrm{p}=0.001$ for $\mathrm{CIINH}-\mathrm{Cl})$, and from the seronegative spondylarthritis group ( $p=0.0007$ for $\mathrm{C} 3 \mathrm{a}$ and $\mathrm{p}=0.001$ for $\mathrm{ClINH}-\mathrm{Cl}$ ). approximately equal groups according to their score for local activity, we found that patients with a higher local activity score (median score in these patients was 6 , range 5-8) had higher concentrations of $\mathrm{C} 3 \mathrm{a}$ and $\mathrm{ClINH}-\mathrm{Cl}$ complexes $(\mathrm{p}<0.05)$ than patients with a lower score (median 3, range $2-4$ ) (fig 2).

Table 4 Relation between parameters of complement activation, CIINH species, and neutrophil parameters in synovial fluid using Spearman rank correlation analysis

\begin{tabular}{lrrr}
\hline & $r^{*}$ & $p$ & $n f$ \\
\hline ClINH-Cl complexes & & & \\
Leucocytes & 0.18 & 0.27 & 38 \\
C3a & 0.78 & 10 15 & 67 \\
iCliNH & 0.68 & 10.010 & 67 \\
Functional index CIINH & -0.32 & 0.007 & 67 \\
Lactoferrin & 0.29 & 0.016 & 66 \\
C3a & & & \\
Leucocytes & 0.30 & 0.06 & 40 \\
Lactoferrin & 0.58 & 107 & 70 \\
iCliNH & 0.67 & 1010 & 70 \\
Functional index CIINH & -0.36 & 0.002 & 70
\end{tabular}

${ }^{*}$ Correlation coefficient.

†Number of patients with the two parameters recorded.
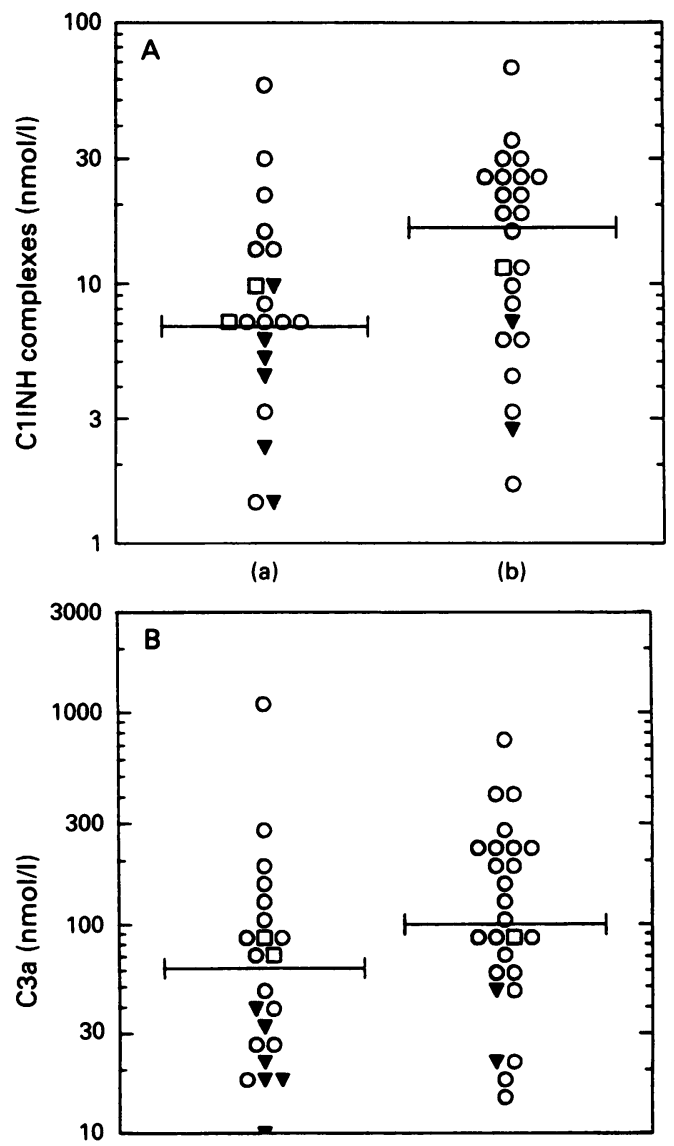

(a)

(b)

Figure 2 Relation between complement activation and local activity of joints. Synovial fluid concentrations of $C I I N H-C 1$ complexes $(A)$ and $C 3 a(B)$ in patients with rheumatoid arthritis ( 37 patients for $C 3 a, 34$ patients for CIINH-CI) (O), gout (three patients) ( $\square)$, and seronegative spondyloarthropathies (eight patients) ( $\nabla$ ) are shown. Patients were divided into two groups based on the local activity (see under Methods) of the aspirated joint: (a) local activity score $<5$ (22 patients), and (b) local activity $\geqslant 5$ (26 patients). The difference in $C 3 a$ and $C I I N H-C 1$ complexes between groups $(a)$ and $(b)$ was significant $(p<0.05$ for both). The straight line indicates the median of the patient group. 
COMPLEMENT ACTIVATION IN PLASMA

In 71 patients with inflammatory arthropathies, plasma concentrations of $\mathrm{C} 3 \mathrm{a}$ and $\mathrm{Cl}-\mathrm{ClINH}$ were higher than in 28 healthy controls $(\mathrm{p}=$ 0.006 and $p<0.0001$, respectively) (table 3 ). Increased concentrations of C3a (i.e. $>7 \mathrm{nM}$ ) and of ClINH-Cl complexes (i.e. $>18 \mathrm{nM}$ ) were found in 18 and $15 \%$ of patients with inflammatory arthropathies respectively. Plasma concentrations of $\mathrm{C} 3 \mathrm{a}$ correlated with concentrations of $\mathrm{ClINH}-\mathrm{Cl}$ complexes $(\mathrm{r}=\mathbf{0 . 3 5}$; $\mathrm{p}=0.004)$ and C3a and C1INH-Cl complexes correlated with concentrations of $\mathrm{iClINH}$ $\left(\mathrm{r}=0.28 ; \mathrm{p}=0.019\right.$ and $\left.\mathrm{r}=0.47 ; \mathrm{p}<10^{-5}\right)$. Plasma C3a correlated with the Ritchie index in 49 patients $(r=0.40 ; p=0.004)$, and higher plasma concentrations of $\mathrm{C} 3 \mathrm{a}$ were found in the 24 patients with more than four painful joints $(\mathrm{p}=0.0077)$.

\section{Discussion}

The complement system and the contact system have been implicated as major contributors to the inflammatory reaction in arthritis. Whereas activation of the complement system has been well established in inflammatory joints, however, ${ }^{7-1131}$ studies of the contact system in arthritis are rare. In this study we analysed for the first time the extent of complement and contact activation in the same patients and assessed the contribution of the two systems to neutrophil activation and clinical symptoms.

In vitro observations that the contact system is activated by exposure to connective tissue elements $^{32}$ and urate crystals ${ }^{33}{ }^{34}$ suggested that activation of the contact system is a major source of kinins in inflammatory arthritides such as RA and gout. With assays for factor XIIa- and kallikrein-C1INH complexes which can detect $0.05 \%$ of activation of factor XII and prekallikrein, ${ }^{23}$ we found that in arthritic joints the contact system is activated only in approximately $20 \%$ of patients with inflammatory arthropathies. Synovial fluid concentrations of complexes did not differ between patients with a higher or a lower local activity, nor between the different patient groups. These observations do not support the hypothesis that the contact system is important in the inflammatory reactions in arthritis.

In plasma from patients with arthritis we rarely found increased concentrations of C1INH-factor XIIa or C1INH-kallikrein complexes. Plasma concentrations of prekallikrein were, however, lower in patients with RA compared with patients with gout and healthy controls. An explanation for this observation could be that the prekallikrein concentration was lowered due to consumption, most likely caused by contact activation. The observed normal plasma concentration of factor XII can be explained by the fact that during contact activation one mole of factor XIIa can activate three moles of kallikrein, thus three times more C1INH-kallikrein than C1INH-factor XIIa complexes are formed. ${ }^{23}$ The absence of C1INH-kallikrein and C1INH-factor XIIa complexes in plasma was presumably due to the low grade of activation and to the rapid clearance of the complexes from the circulation. Con- clusively, these data may point to a systemic low grade activation of the contact system in some patients with inflammatory joint diseases. As it did not correlate with clinical symptoms, however, the relevance of this activation is not clear. In contrast with contact activation, complement activation, as reflected by $\mathrm{C} 3 \mathrm{a}$ (and C5a) concentrations, was found in most synovial fluid samples from arthritic joints. Concentrations appeared to be in the same range as those reported by Moxley and Ruddy, ${ }^{9}$ but substantially higher than those reported by Wagner and Hugli. ${ }^{35}$ Also, in synovial fluid from patients with gout and seronegative spondyloarthropathies increased $\mathrm{C} 3 \mathrm{a}$ concentrations were found, the amount of $\mathrm{C} 3 \mathrm{a}$ being lower in synovial fluid from patients with seronegative spondyloarthropathies than in patients with other inflammatory joint diseases. In addition, C1INH-Cl complexes were often increased (38\%) in synovial fluid from patients with RA and not in synovial fluid from other inflammatory joint diseases and osteoarthritis, in agreement with one previous study. ${ }^{31}$ Concentrations of these complexes correlated with $\mathrm{C} 3 \mathrm{a}$, suggesting that most of the $\mathrm{C} 3 \mathrm{a}$ in synovial fluid from patients with RA was generated via the classical pathway. The complement activation observed in the other inflammatory joint diseases is presumably due to the presence of activators other than immune complexes, such as urate crystals in gout. ${ }^{36-38}$

Few clinical studies have compared the degree of local clinical inflammation with the levels of intra-articular complement activation. As a measure of local activity we used a summated score of four clinically assessed parameters: increased warmth, effusion, swelling, and tenderness. We found that local activity was higher in patients who had more pronounced intra-articular complement activation. This is in keeping with the study of Doherty et al. ${ }^{10}$ though these workers reported a larger difference between higher and lower local activity. This can in part be attributed to the fact that they excluded patients with an intermediate activity from their analysis. Also concentrations of $\mathrm{ClINH}-\mathrm{Cl}$ complexes were higher in patients with a high local activity score. This is not surprising as 37 of the patients in whom local activity was assessed had RA, and activation of the classical pathway of the complement system (by immune complexes) is probably the main route for complement activation in RA. ${ }^{78}$ Mollnes and Paus ${ }^{11}$ did not find a correlation between complement activation and clinical activity of the joint expressed as a functional score (the knee score). This is presumably explained by the fact that this knee score results from ongoing and previous processes, whereas the amount of complement activation in synovial fluid is the result of processes occurring at the time of the arthrocentesis.

ClINH is the most important inhibitor of activated $\mathrm{Cls}$ and $\mathrm{Clr}$, and of kallikrein and factor XIIa. ${ }^{20-22}$ The plasma concentration of CIINH was higher in patients with inflammatory arthropathies than in healthy volunteers, in agreement with its acute phase behaviour. ${ }^{39}$ 
The functional index of CIINH and the fraction of inactivated CIINH in plasma did not differ significantly between patient groups, though occasional patients showed a fraction of inactivated CIINH two to three times the normal level. This is in keeping with the higher fractional catabolic rate of CIINH observed in some patients with RA. ${ }^{40}$ The correlation of inactivated $\mathrm{ClINH}$ with $\mathrm{C} 3 \mathrm{a}$ and $\mathrm{ClINH}-\mathrm{Cl}$ suggest that inactivated CIINH was the result of complement and not of contact activation. Analysis of C1INH in synovial fluid of patients with arthritis showed no major abnormalities. Increased synovial fluid concentrations of inactivated C1INH that were occasionally observed correlated with complement activation (table 4) and thus presumably also resulted from complement activation.

Neutrophils are the predominant cells present in arthritic joints. ${ }^{1} 241$ The observed correlation between complement activation and neutrophil counts or neutrophil activation products, or both, by several workers ${ }^{11-13}$ and in this study suggests that split products of complement components are the predominant chemoattractants or agonists, or both, for these cells in arthritis. Kallikrein and factor XIIa have been shown in vitro to possess chemotactic or agonistic activity, or both, for neutrophils. ${ }^{15-1742}$ The absence of any relation between C1INH-kallikrein complexes or other contact system parameters and neutrophil parameters suggests that this phenomenon does not have a pathogenetic role in arthritis.

In conclusion, in arthritic joints the contact system was activated only in occasional patients. In contrast, activation of the complement system was a general finding in arthritic joints, and appears to be responsible for the local inflammatory reaction and the influx and activation of neutrophils in arthritis.

This study was financially supported by The Dutch Rheumatism Foundation (grant no. 89/CR/225/89).

1 Brown K A. The polymorphonuclear cell in rheumatoid arthritis. $\mathrm{Br} \mathcal{F}$ Rheumatol 1988; 27: 150-5.

2 Weissmann G. Activation of neutrophils and the lesions of rheumatoid arthritis. F Lab Clin Med 1982; 100: 322-33.

3 Hadler N M, Spitznagel J K, Quinet R J. Lysosomal enzymes Hadler N M, Spitznagel J K, Quinet R J. Lysosomal enzymes
in inflammatory synovial effusions. $\mathcal{F}$ Immunol 1979; 123: $572-6$.

4 Kleesiek K, Reinards R, Brackertz D, Neumann S, Lang H, Greiling $H$. Granulocyte elastase as a new biochemica marker in the diagnosis of chronic joint diseases. Rheumato Int 1986; 6: 161-9.

5 Vogt W. Anaphylatoxins: possible roles in disease. Complement 1986; 3: 177-88.

6 Kaplan A P. The intrinsic coagulation, fibrinolytic and kinin forming pathways of man. In: Kelley $W N$, Harris $E D$, Ruddy S, Sledge C B, eds. Textbook of rheumatology. Philadelphia: Saunders, 1985: 95-114.

7 Nydegger U E, Zubler R H, Joliat G G, Karagevrekis Ch, Lambert P H, Miescher P A. Circulating complement breakdown products in patients with rheumatoid arthritis. breakdown products in patients

8 Perrin L H, Nydegger U E, Zubler R H, Lambert P H, Miescher P A. Correlation between levels of breakdown Miescher $\mathrm{P} A$. Correlation between levels of breakdown
products of $\mathrm{C} 3, \mathrm{C} 4$, and properdin factor $\mathrm{B}$ in synovial products of C3, C4, and properdin factor B in synovial
fluids from patients with rheumatoid arthritis. Arthritis fluids from patients with
Rheum 1977; 20: 647-52.

9 Moxley G, Ruddy S. Elevated C3 anaphylayoxin levels in synovial fluids from patients with rheumatoid arthritis. Arthritis Rheum 1985; 28: 1089-95.

10 Doherty M, Richards N, Hornby J, Powell R. Relation between synovial fluid $\mathrm{C} 3$ degradation products and local inflammation in rheumatoid arthritis, and crystal induced arthropathy. Ann Rheum Dis 1988; 47: 190-7.

11 Mollnes T E, Paus A. Complement activation in synovia fluid and tissue from patients with juvenile rhematoid arthritis. Arthritis Rheum 1986; 29: 1359-64.

12 Hunder G G, McDuffie F C, Mullen B J. Activation of complement component $\mathrm{C} 3$ and factor $\mathrm{B}$ in synovial fluids. f Lab Clin Med 1977; 89: 160-71.

13 Berkowicz A, Kappelgaard E, Petersen J, et al. Complement
C3c and C3d in plasma and synovial fluid in rheumatoid arthritis. Acta Pathol Microbiol Immunol Scand Sect C 1983; 91: 397-402.

14 Cochrane C G, Griffin J H. The biochemistry and pathophysiology of the contact system of plasma. Adv Immunol 1982; 33: 241-304.

15 Kaplan A P, Kay A B, Austen K F. A prealbumin activator of Kaplan A P, Kay A B, Austen K F. A prealbumin activator of
prekallikrein. II. Appearance of chemotactic activity for neutrophils by the conversion of human prekallikrein to kallikrein. f Exp Med 1972; 135: 81-97.

16 Schapira M, Despland E, Scott C F, Boxer L A, Colman R W Purified human plasma kallikrein aggregates human blood neutrophils. F Clin Invest 1982; 69: 1199-202.

17 Schapira M, Henry J, Wachtfogel Y T, et al. A role for plasma kallikrein in rheumatoid arthritis. Clin Res 1983; 31 : 454A.

18 Melmon K L, Webster M E, Goldfinger S E, Seegmiller J E. The presence of a kinin in inflammatory synovial effusion from arthritides of varying etiologies. Arthritis Rheum 1967; 10: $13-20$.

19 Keele C A, Eisen V. Plasma kinin formation in rheumatoid arthritis. Adv Exp Med Biol 1970; 8: 471-5.

20 Pixley $\mathrm{R}$ A, Schapira M, Colman $\mathrm{R}$ W. The regulation of human factor XIla by plasma proteinase inhibitors. $\mathcal{J}$ Biol human factor XIla by plasm

21 van der Graaf F, Koedam J A, Bouma B N. Inactivation of kallikrein in human plasma. $\mathcal{J}$ Clin Invest 1983; 71 : 149-58.

22 Sim R B, Reboul A, Arlaud G J, Villiers C L, Colomb M G Interaction of ${ }^{125}$ I-labelled complement subcomponents $\mathrm{Clr}$ and $\mathrm{Cls}$ with protease inhibitors in plasma. FEBS Let 1979; 97: 111-5.

23 Nuijens J H, Huijbregts C C M, Eerenberg A J M, et al. Quantification of plasma factor XIIa-Cl-Inhibitor and 1841-8.

24 Hack C E, Paardekooper J, Eerenberg A J M, et al. A modified competitive inhibition radioimmunoassay for the modified competitive inhibition radioimmunoassay for the
detection of C3a. Use of 1251-C3 instead of 1251-C3a. detection of C3a. Use of 1251-C3 in
$\mathcal{f}$ Immunol Methods 1988; 108: 77-84.

25 Arnett F C, Edworthy S M, Bloch D A, et al. The American Rheumatism Association 1987 revised criteria for the classification of rheumatoid arthritis. Arthritis Rheum 1988; 31: 315-24.

26 Wallace S L, Robinson H, Masi A T, Decker J L, McCarty D J, Yü T. Preliminary criteria for the classification of the acute arthritis of primary gout. Arthritis Rheum 1977; 20: 895-900.

27 Moll J M H, Wright V. New York clinical criteria for ankylosing spondylitis. Ann Rheum Dis 1973; 32: 354-63.

28 Prakash S, Mehra N K, Bhargava S, Malaviya A N. HLA B27 related 'unclassifiable' seronegative spondyloarthroB27 related 'unclassifiable' seronegative ssot
pathies. Ann Rheum Dis 1983; 42: 640-3.

pathies. Ann Rheum Dis 1983; 42: 640-3.
29 Hack C E, Hannema A J, Eerenberg A J M, Out T A Aalberse R C. A C1-inhibitor-complex assay (INCA): a method to detect $\mathrm{Cl}$ activation in vitro and in vivo. f Immunol 1981; 127: 1450-3.

30 Nuijens $J \mathbf{H}$, Eerenberg-Belmer $A \mathrm{~J} M$, Huijbregts $C \mathrm{C} M$, $e t$ al. Proteolytic inactivation of plasma Cl-Inhibitor in sepsis. F Clin Invest 1989; 84: 443-50.

31 Inman $\mathrm{R}$ D, Harpel P C. Cl inactivator-Cls complexes in inflammatory joint disease. Clin Exp Immunol 1983; 53 : 521-8.

32 Moskowitz R, Schwartz R J, Michel B, Ratnoff O D, Astrup T. Generation of kinin-like agents by chondroitin sulfate, and human articular cartilage: possible pathophysiologic implications. F Lab Clin Med 1970; 776: 790-8.

33 Kellermeyer $\mathrm{R}$ W, Breckenridge $\mathrm{R}$ T. The inflammatory process in acute gouty arthritis. Activation of Hageman process in acute gouty arthritis. Activation of Hageman 307-14.

34 Ginsberg M H, Jaques B, Cochrane C G, Griffin J H. Urate crystal-dependent cleaveage of Hageman factor in human plasma and synovial fluid. $\mathcal{F} \mathrm{Lab}$ Clin Med 1980; 95: 497-506. 35 Wagner J L, Hugli T E. Radioimmunoassay for anaphyla-
toxins: a sensitive method for determining complement activation products in biological fluids. Anal Biochem 1984 136: 75-88.

36 Byers P H, Ward P A, Kellermeyer R W, Naff G B. Complement as a mediator of inflammation in acute gouty arthritis. II. Biological activities generated from complement by the interaction of serum complement and sodium urate crystals. F Lab Clin Med 1973; 81: 761-9.

37 Hasselbacher P. C3 activation by monosodium urate monohydrate and other crystalline material. Arthritis Rheum 1979; 22: 571-8.

38 Doherty $M$, Whicher J T, Dieppe P A. Activation of the alternative pathway of complement by monosodium urate monohydrate crystals and other inflammatory particles. $A n n$ Rheum Dis 1983; 42: 285-91.

39 Kalter E S, Daha M R, Ten Cate J W, Verhoef J, Bouma $B$ N. Activation and inhibition of Hageman factor-dependent pathways and the complement system in uncomplicated bacteremia or bacterial shock. $\mathcal{F}$ Infect $D i s$ 1985; 151 : 1019-27

40 Woo P, Lachmann P J L, Harrison R A, Amos N. Simultaneous turnover of normal and dysfunctional $\mathrm{Cl}$ Inhibitor as a probe of in vivo activation of $\mathrm{Cl}$ and contact activatable proteases. Clin Exp Immunol 1985; 61: 1-8.

41 Schumacher H R. Synovial fluid analysis. In: Kelley W N Harris E D, Ruddy S, Sledge C B, eds. Texibook of rheumatology. Philadelphia: Saunders, 1985: 561-7.

42 Colman R W, Wachtfogel Y T, Kucich U, et al. Effect of cleavage of the heavy chain of human plasma kallikrein and its functional properties. Blood 1985; 65: 311-8. 